\title{
Variation in the Speech of Two Palestinian Immigrant Groups
}

\section{Варіації в мовленні двох палестинських імміграційних груп}

\author{
Mahmoud El Salman \\ $\mathrm{Ph}$. D. in Linguistics, \\ Professor
}

Махмуд Ель Салман

доктор філософії (Ph. D.) в галузі

лінгвістики, професор

\author{
E-mail: el_salman@hotmail.com \\ https://orcid.org/0000-0001-8085-9533
}

University of Petra, Jordan

P.O.BOX 961343, Amman, Jordan, 11196
Університет Петри, Йорданія

$\triangle$ P.O.BOX 961343, Амман, Йорданія, 11196

Original manuscript received March 01, 2021

Revised manuscript accepted October 13, 2021

\begin{abstract}
Objectives. This sociolinguistic study aims to take a close look at the differences and similarities in the linguistic behavior of two Palestinian groups and analyze these in light of social and political factors.

Methods. The study adopts the Labovian Paradigm, and face-to-face techniques are used to collect data.

Results. The first group immigrated to Jordan from Palestine as a result of being forced from their homes in 1948. They came seeking refuge in Jordan, and, because they came from Palestine, they were treated as such. When the Arab-Israeli war began nearly two decades later, a new wave of Palestinians migrated to Jordan in 1967. Yet, at this time, their Palestinian village belonged to Jordan, politically, because Jordan had annexed the West Bank in 1950. Thus, the political status of both sets of Palestinians at the beginning of their exodus played a major role in the subsequent development of their linguistic behavior in Jordan. It influenced the kind of variation that occurred in their speech. The first people to arrive were treated as Palestinian refugees, which minimized them from a social perspective. Thus, the study shows
\end{abstract}


that the middle-aged and younger generations of this ethnic group abandoned their dialect, and $98.0 \%$ of them adopted the local variant. The individuals of the second set of migrants were treated as Jordanian citizens as they had simply migrated from one part of the country, namely, the West Bank, to another part of it, namely, the East Bank (Jordan). The study found a strong correlation between an individual's identity and the political status granted by a country. Though the members of both groups are Palestinians, the study shows that all individuals behaved linguistically differently depending how they were perceived socially and politically in Jordan.

Conclusion. Palestinians emigrated in two large waves from their homeland to Jordan as the result of war. The first took place in 1948, and the second took place in 1967. The study shows that the linguistic behavior of both groups differs. The social and the political situations that each group found itself in determined, to a great extent, the linguistic behavior they adopted.

Key words: linguistic behavior, variant, speech community, identity.

\section{Introduction}

Palestinians immigrated to Jordan in two large waves as a result of a forced migration due to the Arab-Israeli wars. The first wave occurred when they were forced to leave their homeland in 1948; the second wave occurred in 1967 when the Israelis occupied the rest of the country. In 1917, for example, Palestinians lived on their land, and

"[a]t that time, Palestine, a country roughly the size of Wales, had a population of approximately one million. There were one Jewish town, thirty-four Jewish colonies, fourteen Arab towns, 612 Arab villages and five mixed population towns. Arabs formed 92 percent of the population" (Low, 2008: 1).

In his 1908 account of the Mount Carmel region of Palestine, Muelinen stated that

"[t]he native Carmel population is primarily composed of two groups, the resident peasants (Fellāheen) and the nomadic Bedouins (bedu or 'urbān)" (Muelinen, 1908: 40)

and

"[t]he dominant faith is orthodox Sunni Islam" (Muelinen, 1908: 42).

This study's researcher belongs to the Fellaheen group (the peasant group), and this group and other Palestinians immigrated to Jordan as 
a result of the war in 1948. My family comes from the village of et-Tire which was described by Muelinen in 1908 as

"Et-tîre is the most significant community of Mount Carmel, and its region covers a large portion of the mountain as well as the western coastal plain. Along with the smaller scattered settlements belonging to it, it counts 2.435 residents. The field of et-tīre once stretched from tell es-semek in the north up towards dustre and from the ocean in the west until the wilderness on the Carmel Ridge (min il-bahr lil-wa'r)" (Muelinen, 1908: 130).

The Arabic language was the dominant language in the area, and, according to Muelinen,

"[t]he predominant dialect on Mount Carmel is the Arabic Fellāheen ("peasant") dialect of Middle Palestine which actually varies among the towns and villages but still creates a unique middle group between that of the urban population and the Bedouins" (Muelinen, 1908: 20).

Those 2.435 residents, who increased to nearly 10.000 in 1948 according to UNRWA sources (El Salman, 1991), were forced to immigrate from their village, as was the case for other Palestinians, and found themselves stripped of their homes and fields which had stretched for tens of kilometers. They lived in tents in refugee camps in Jordan that later became small houses made of clay and wood in a city they never had seen before called Irbid. They had become refugees after being owners of farms and orchards and houses that were built of stones of the kind described by Eric Low,

"Arab villages on the plain were often made of unfired clay but Tirah was built of stones on the slopes of the hill" (Low, 2008: 108).

As they were a very important group in Palestine, Muelinen states that their dialect was used as a basis on which he depended for conducting his linguistic study in the area. According to Muelinen,

"[i]n order to observe to the required consistency in the reproduction of the sounds, the example of the people from et-tire, whose fields lie on the larger portion of the mountain, is taken as a basis" (Muelinen, 1908: 20).

The dialect of this group had been dominant and thus adopted by many in Palestine, but now it faced the risk of disappearing as a result of their immigration. 
According to Myers-Scotton,

"[f]irst language attrition among adults often happens among immigrants when they join a community where another language is sociolinguistically dominant and the speaker becomes bilingual in this language. Of course, under such circumstances, language shift by the second generation often occurs" (Myers-Scotton, 1997: 225).

A new community means the experience of moving to a new home,

"but, for cross-language immigrants, the new home is accompanied by a new culture, new laws, and a new language" (Esposito \& Baker-Ward, 2016: 949).

In such situations, migrants feel that they are rendered socially insignificant, and, as a result, the use of a non-local dialect might not be received without a social cost. Thus, this could lead to the abandonment of one's dialect in favor of the dialect of the socially dominant group. According to Myers-Scotton,

"a major motivation for using one variety rather than another as a medium of an interaction is the extent to which this choice minimizes costs and minimizes rewards for the speaker" (Myers-Scotton, 1995: 100).

There were no Palestinians living in Jordan when this group (henceforth, the Tirawis) arrived in Jordan. The Jordanians gave them a very friendly welcome and treated them as brothers (El Salman, 2006). Nevertheless, they suffered socially and financially as they had lost their houses, land and, above all, their identities. They also lost their language. They had been native residents in their country and had now become refugees. The psychological impact of this affected their state of mind. They began to view themselves in a new light; they were no longer Palestinian Tirawis, but rather they became Jordanians who were originally Palestinians. This new identity necessitated a change not only in the lifestyle they had been accustomed to but also in the tongue as they were coping with the new life in a new land. People approach a new culture and new names of new tribes with reluctant acceptance as they have reservations toward accepting anything that belongs to a tribe to which they are not members (Raymond, 2019) 


\section{Methods}

My study is empirical in its methods in that it is fully dependent on naturalistic speech. All the interviews, which were conducted in Irbid (Jordan), were carried out using the face-to-face technique for obtaining data with regard to linguistic variation. All sample subjects of this study gave full consent to participate in the research. The study is comprised of Jordanians who are either originally from al-Tira in Palestine and who migrated to Irbid as a result of the Arab-Israeli war in 1948 or their descendants and Silawis who are originally from Al Silah in Palestine and who migrated to Irbid as a result of Arab-Israeli war in 1967 or their descendants.

I am a member of the Tirawi group, so I did not encounter any difficulties in interviewing the people of this group and was able to select the required samples easily. I also conducted similar interviews with the Silawis. Although I am not a member of this group, I grew up with them in the same neighborhood so I was also able to conduct interviews within this sample easily. Furthermore, I have maintained good relations with Silawis who have left the neighborhood. This also gave me the chance to observe their speech in their new locations. Thus, I have been able to continue to observe the speech of Silawi individuals. As a result, my large social network within the two groups enabled me to draw my sample from a variety of people and from both genders. It is not easy to interview female informants in the Arab world. This is a very problematic issue in the Arab world and has led some sociolinguists to exclude females from their study as in the case of Al-Jehani in his study on Makkan Arabic (Saudi Arabia) because of the cultural norms restricting women's contact with men (Al Jehani, 1985). Other researchers have engaged a female assistant to help conduct their interviews with females as in the case of Al Khatib in his 1988 study in Irbid (Jordan) and Daher in his 1998 study in Damascus.

The interview questions were designed to prompt the informants to talk about their experiences and recollections of their native villages or the recollections of their parents that they may have heard recounted. Nevertheless, it should be acknowledged that sometimes it was not easy to encourage people to talk about their experiences from the time of the war. The survivors of war rarely spoke of their experiences to their children as 
"[b]ased upon the literature, we can see that this is a common reaction to trauma" (Cho Kim, 2019: 919).

Subjects who hesitated to answer this type of question were asked questions about the culture of the village and its social life. An informant who had been injured in the war in 1948, for example, broke out in tears when asked about her experience in the war. Wartime memories, particularly traumatic ones, have extreme psychological consequences on survivors.

I have noticed that the younger generations often take note of this negative psychological effect as well. Nevertheless, they showed more enthusiasm for talking about what they have heard from their family about the war. For others, discussing the war elicited the emergence of spontaneous speech as the trauma of telling the stories distracted from concentration on the style of speech. It was also noted that some of the survivors, particularly females, pretended that they remembered nothing about the native village and its traditions and social life. Given the fact that I know the ages of some of the participants, I knew they were of an age that could remember the details. However, they chose to not reveal this knowledge to hide their age. Recalling the village will reveal that they are older than they claim. The technique I used in such cases was to ask them to inform me about what they heard from their parents. Thus, they began recounting what they personally know while claiming that they had heard these things from others. Some interviewees even hid their original dialect and pretended that they had minimal knowledge of it because they were too young when they were forced to leave their native village. Throughout the interviews, I succeeded in prompting this hidden dialect to emerge.

Forty-eight informants were interviewed in each group as shown in Table 1.

\section{Table 1}

Distribution of informants by sex and age

\begin{tabular}{|c|c|c|c|}
\hline Sex & $\mathbf{M}$ & $F$ & Total \\
\hline Young & 8 & 8 & 16 \\
\hline Middle & 8 & 8 & 16 \\
\hline Elderly & 8 & 8 & 16 \\
\hline Total & 24 & 24 & 48 \\
\hline
\end{tabular}


I divided the sample into three groups according to education, gender and age. In order to gain a statistically accurate view of the use of the variables, a univariate analysis is employed. For the purpose of using the univariate analysis, each group is presented as a number.

\section{Adherence to Ethical Standards}

All sample subjects of this study gave full consent to participate in the research. They were informed about the interviews and they gave me a full permission to be interviewed.

\section{Results}

The results of research were presented in the repository Harvard (El Salman, 2021).

\section{The Dialect of Tirawis before 1948}

The key feature of the dialect of al-Tira is the uvular stop [q]. The variable $(\mathrm{Q})$ has four major variants: the voiceless uvular stop [q], the voiced velar stop $[\mathrm{g}]$, the voiceless velar stop $[\mathrm{k}]$ and the glottal stop [?]. For the purpose of this study, three variants will be considered. These are: the voiceless uvular stop [q], generally considered the SA variant while in this study it is also part of the native Tirawi dialect; the voiced velar stop [g], the local variant of Irbid; and the glottal stop [?], an important urban variant and has also been adopted by some Tirawis. The voiceless velar stop [k] will not be considered as it is neither part of the Tirawi dialect nor part of "the speech of Horanis [the local people of Irbid]" (Al Khatib, 1988: 89). Nor is the [k] variant used by any of the informants. It is typically found in the rural dialects of central Palestine (Al Khatib, 1988: 82; Amara et al., 1999: 67; Al Zu'bi, 2001: 93).

This key feature is used to measure the variation in the speech of the Tirawis as

"the key feature $[q]$ became indissolubly linked with the Tirawis. It has become an identity feature for a Tirawi whether he or she uses it or not" (El Salman, 2003: 8).

The study I conducted in 2003 revealed the following with regard to this group. 
Table 2 shows that the [q] variant is used 100\% among elderly males and $98.0 \%$ among elderly females of the total number of occurrences of the $(\mathrm{Q})$ variable. In the remaining $2.0 \%$ of cases, elderly females use the variant of the $(\mathrm{Q})$ variable. Thus, innovation in this area can be seen among elderly females, despite that it is only marginally discernible in this case. SPSS statistical analysis also shows that age is very significant in the use of the $[\mathrm{q}]$ variant $(\mathrm{P}<.05$ while $\mathrm{P}<000$ for age with regard to the use of the $[\mathrm{q}])$.

\section{Table 2}

The distribution of the variable (Q) by age and sex

\begin{tabular}{ccccccccc}
\hline Gender & \multicolumn{3}{c}{ M } & \multicolumn{3}{c}{$\mathbf{F}$} \\
\hline $\begin{array}{c}\text { Age } \\
\mathbf{k}]\end{array}$ & {$[\mathbf{k}] \%$} & {$[\mathbf{g}] \%$} & {$[\mathbf{?}] \%$} & $\mathbf{N}$ & {$[\mathbf{k}] \%$} & {$[\mathbf{g}] \%$} & {$[\mathbf{?}] \mathbf{\%}$} & $\mathbf{N}$ \\
\hline Young & 9.0 & 81.0 & 10.0 & 528 & 8.0 & 2.0 & 90.0 & 517 \\
Middle & 78.0 & 22.0 & 1.0 & 514 & 68.0 & 12.0 & 20.0 & 453 \\
Elderly & 90.0 & 8.0 & 2.0 & 532 & 85.0 & 5.0 & 10.0 & 510 \\
\hline
\end{tabular}

Figure 1 also displays this pattern in the use of [q]. It shows that there is a general increase in the use of [q] from young to old and that the peak occurs in the elderly age group.

Figure 1

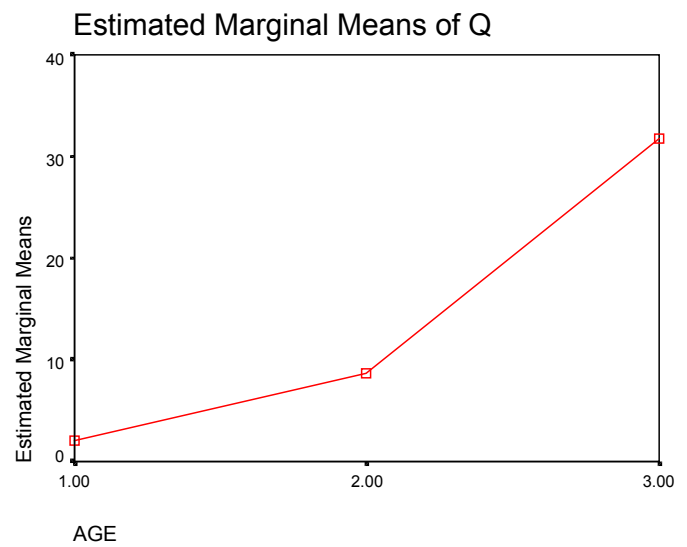

Linguistically, both females and males in the elderly age group behaved similarly in that they categorically preserved the [q] variant. SPSS analysis shows that gender, by contrast, has a very low significance in the use of the $[\mathrm{q}]$ variant $(\mathrm{P}<.05$ while $\mathrm{P}<.278$ for gender 
in the use of the [q] variant). The crucial factor, therefore, is age. It is a very well-known fact that the elder members of a group are subject to much more pressure from society to preserve their native dialect than the younger generations (Al-Wer, 1991: 91; Walters, 1991: 201). Eckert also reports that

"community studies of variation frequently show that increasing age correlates with increasing conservatism in speech" (Eckert, 1997: 157).

In the case of women, we can add the factor of contact. Generally, in Arab societies, women have less contact with the outside world than men, and the social contact between them is greater than that between men. Bakir notes that

"women, being restricted to domestic chores and each other's company, have a narrower social network and do not have the opportunity or need to use the standard forms" (Bakir, 1986; cited in Mazraani, 1997: 3).

The table shows that there is a drastic decrease in the use of the native [q] variant among the members of the middle-aged group. The rate of use is $10.0 \%$ among males and $6.0 \%$ among females. This drastic decrease is due to the fact that most of the people in the middle-aged group were born in Jordan (i.e. persons under 53 years old). In addition, a small number in this age group were born before the 1948 war, but they were younger than 4 years old at the time. In other words, they were too young to have mastered their native dialect and for this dialect to have established lasting roots. Thus, they do not differ linguistically from other people in their age group who were born in Jordan after the war. In contrast, all the members of the older age group were born in the villages where the native dialect was dominant. The likelihood of using the original vernacular forms should be higher among this group. In addition, the interest in prestige is assumed to be lower among the members of the elderly group than the members of the middle-aged group as the pressure upon the elders is higher.

The younger generation does not preserve the native [q] variant. The [q] shows as $6.0 \%$ use among young males and 3\% among young females. In general, they try to follow the patterns which they believe embody the social meanings they seek. The fact that there is less social pressure on the young than on the elderly in Jordanian societies 
(Al-Wer, 1991) also helps the younger generation introduce sound shifts since such an innovative behavior pattern could not pass without much criticism by the community.

\section{The Silawi Group}

Unlike the Tirawis, Silawis (i.e. people from Al Silah) began migrating to Jordan in large numbers in 1967 as a result of Israeli occupation of their village during the Arab-Israeli war. The vast majority of these migrants settled in the city of Irbid in the northern part of Jordan. It should be noted that although this group is originally from Palestine, Al Silah was part of the West Bank which was part of Jordan in 1967. This is a crucial differentiating factor between these two Palestinian groups, namely, the Tirawis and the Silawis. After the Arab-Israeli war in 1948, this region of Palestine (the West Bank) was annexed by Jordan. This led to King Hussein's federation plan, or the United Arab Kingdom, which aimed to join the West Bank region and the East bank.

Thus, this group is ethnically Palestinian based on their origins, but in terms of politics and nationality, the members of this group are Jordanians. All Palestinians in Jordan were granted Jordanian citizenship. According to Kanovsky,

"[u]nlike the other Arab states, Jordan granted Jordanian citizenship en bloc to all the refugees in its territory and made efforts towards their integration and absorption in the Kingdom" (Kanovsky, 1976: 4).

So, when talking about Silawis, people do not say these people "laja'o" to Jordan, i.e. "they migrated to Jordan". Instead, people say "nazaho" to Jordan, or "moved to", giving the impression that they are not foreigners but they are Jordanian citizens who have simply moved from one place in the country (Al Silah) to another place (Irbid). Thus, Tirawis were described as "Laj'iin" (refugees) while Silawis are not described as refugees. This also gives the Silawis the impression that they still have a home, and they have the intention to stay. While Tirawis came to Jordan with the belief that their exodus from their homeland would only be temporary. Indeed,

"[o]ne of the factors that might influence immigrant integration is whether, upon arrival, they intend to stay in the host society" (Wachter \& Fleischmann, 2018: 155). 
The West Bank remained part of Jordan, even after the war of 1967, until Jordan severed administrative ties with the West Bank in a decision known as disengagement, ${ }^{*}$ or "Fak alairtibat", between the Hashemite Kingdom of Jordan and the West Bank in 1988. Persons originally from Al Silah but residing in Jordan at the time were considered Jordanians after this political disengagement. The Silawis in Jordan have the right to a national identity number while those who were in the West Bank in 1988 were not issued a national identity number, but they have the right to a 2-year passport in order to facilitate their travel. Members of the first group are described as yellow card holders. These people are considered Jordanian-Palestinians. Members of the second group are described as green card holders. These people are officially considered Palestinians. This is also an important difference between the two groups. The details of this political and social situation and how these people are described and perceived by other people as well as themselves will be used to interpret the integration between linguistic implications, political implications and social implications throughout the study.

Tirawis, in the other hand, are all considered refugees and all have Jordanian citizenship and are now treated as Jordanians who have national identity cards. This crucial difference between Tirawis and Silawis is important to note as it will be used to interpret the reason why the trend of variation in their speech differs. For example, the Tirawis have a UN card that verifies their refugee status. The card is a reminder to them that they are refuges and the UNRWA (United Nations Relief and Works Agency) is responsible for them in one way or another. UNRWA schools, for example, are available to Tirawis but they are not available to Silawis.

It should also be understood that the sample of my study consists of individuals who migrated from Al Silah (Palestine) in 1967. They are Jordanian citizens and have a national identity card. They are unable to return to their original village, as in the case of the Tirawis, but they have many relatives who still live there and they continue to visit them.

\footnotetext{
* Jordanian disengagement

On 31 July 1988, Jordan renounced its claims to the West Bank (with the exception of guardianship over the Muslim and Christian holy sites in Jerusalem) and recognized the Palestine Liberation Organization as "the sole legitimate representative of the Palestinian people".
} 
Thus, for them, dialect contact with the original dialect is still a constant expectation and occurrence. Therefore, they are not classified as belonging to either of the previously mentioned groups. The group to which these people belong can occupy any political position in the Kingdom, similar to the Tirawis.

\section{The dialect of this group}

The village of Al Silah is also known as Silat Al Dhahir (i.e. the Silah of Al Dahir) in order to distinguish it from other places in Palestine also known as Al Silah. For example, there is the village of Silat al Harithiya located northwest of Jenin. In addition, Silat Al Dahir was known as one of the biggest villages in the Jenin governorate, and many people from this village were known for their success. Their affluence is a well-known fact in the area. The people of Al Silah were accustomed to being perceived as persons of prestige when they resided in their village. As a result, the people of Al Silah were proud of themselves, and how others viewed them played a major role in their self-image.

Their dialect is the typical Palestinian dialect in which the voiceless alveolar stop / $\mathrm{k} /$ is used in its phonetic inventory. In addition, the kashkashah is also one of its key phonetic features. However, the unique features of this dialect post-immigration come as a result of the unique social situation in which they found themselves when they arrived in Irbid (Jordan). Thus, while the uvular /q/ variant of the (Q) variable is the key feature of the Tiraiws, the voiceless velar stop / $\mathrm{k}$ / variant of the $(\mathrm{Q})$ variable is the key feature of the Silawi. This was the deciding factor in selecting these two features to measure the variation in the speech of these two groups. For example, a word like /Qalam/, "pen" is pronounced as /qalam/ by Tirawis, and /kalam/ by Silawis. Accordingly, Abdel-Jawad stated that

"because of the social and geographical importance of this variable $[(Q)]$ as a carrier of local or regional loyalties, it has often been used by dialectologists as the main criterion for establishing the dialect boundaries or isolosses in the Arabic dialects" (Abdel-Jawad, 1981: 159).

The study of the Silawi group shows the following results: 
Table 3

The distribution of the variable (Q) by age and gender

\begin{tabular}{|c|c|c|c|c|c|c|c|c|}
\hline \multirow{2}{*}{$\begin{array}{c}\text { Gender } \\
\text { Age } \\
{[\mathrm{k}]}\end{array}$} & \multicolumn{4}{|c|}{$\mathbf{M}$} & \multicolumn{4}{|c|}{ F } \\
\hline & {$[\mathrm{k}] \%$} & {$[\mathrm{~g}] \%$} & {$[?] \%$} & $\mathbf{N}$ & {$[k] \%$} & {$[g] \%$} & {$[?] \%$} & $\mathbf{N}$ \\
\hline Young & 9.0 & 81.0 & 10.0 & 528 & 8.0 & 2.0 & 90.0 & 517 \\
\hline Middle & 78.0 & 22.0 & 1.0 & 514 & 68.0 & 12.0 & 20.0 & 453 \\
\hline Elderly & 90.0 & 8.0 & 2.0 & 532 & 85.0 & 5.0 & 10.0 & 510 \\
\hline
\end{tabular}

Table 3 shows that the $/ \mathrm{k} /$, which is the key feature and the salient feature of the Silawi dialect, is used in a high percentage by the older generation. It is used in $90.0 \%$ of the total number of the occurrences of the (Q) variable by elderly males and $85.0 \%$ by elderly females. Discovering that the elderly members preserve the $/ \mathrm{k} /$ variant is expected as most studies (Al Khatib, 1988, Al Wer, 1991) show that the older generation is always under pressure to preserve their native dialect. In addition, when adapting to their host country, these older adults encounter cultural challenges arising from proximity with adult children (Bum et al., 2019: 378). This may influence them to not interact with the new community. In turn, this helps to enable them to preserve their own dialects. It is also a very well-known fact that "[n]ot all immigrants integrate to the same degree or at the same rate" within the new society (Wachter \& Fleischmann, 2018: 154). The elderly are subject to much more pressure from their society to preserve their native dialect than the young (Al-Wer, 1991: 91; Walters, 1991: 201).

Table 3 also shows that the rate of the use of the $/ \mathrm{k} /$ variant remains very high in the group described as Stair generation (SG) members. It occurs $78.0 \%$ among males and $68.0 \%$ among females who belong to this group. Most of the members of this group lived in the Stair Neighborhood (a neighborhood primarily settled by Silawis) or still live in it. The objective reasons mentioned in the beginning and the exceptional conditions in which residents of this neighborhood live have played major roles in enabling the preservation of their dialect. The social pressure they are subjected to is not comparable to that of the elderly. The social context of this neighborhood is very similar to that of the elderly in their native village in Palestine. They are in the majority; the owners of the houses belong to their ethnic group, and they have the prestige of being relatives of the wealthiest people in this very large 
neighborhood. All of these factors have played a role in making Silawis feel that they are powerful not only socially but also linguistically.

Because they were not linguistically insecure, they did not, as a result, abandon their native dialect in favor of the dominant local variant, namely, the voiced velar stop /g/. Accordingly, leaving a place per se, is not a reason to abandon one's dialect. However, leaving a place is significant and will influence the decision to preserve or to abandon one's dialect if the immigrants feel that they are socially disempowered. This leads to linguistic insecurity; this naturally and automatically leads immigrants to seek to empower themselves socially by adopting the dialect that can help them psychologically feel that they are part of the dominant local group. The residents of this neighborhood did not suffer as immigrants. The fact that the West Bank from which they immigrated was part of Jordan when they came to Jordan attributed to their sense of belonging as they felt they were still living in the same country and thus were local. The fact that they received full Jordanian citizenship also played a role in making them feel that they are Jordanian although they are originally from Palestine (Kanovsky, 1976).

The third important factor was that the Silawis were received by some of their relatives who had already been in Jordan prior to the war of 1967. Those relatives granted them houses for affordable prices. In this neighborhood, they found themselves included in a majority that was socially and, as a result, linguistically secure. Therefore, there was no need to abandon their dialect. In this speech community and in this neighborhood, in particular, we clearly see the interaction of politics, linguistics and society. These people were politically secure in that they held the Jordanian citizenship before emigrating from Palestine to Jordan. Thus, they were not treated as most immigrants in other parts of the world who are only granted citizenship after having settled in the country to which they immigrated. Consequently, they still felt that they had been granted a citizenship that was not originally theirs. The Silawis did not experience this. As a result, they felt socially powerful which led to linguistic security.

The linguistic behavior of the younger generation drastically differs from the linguistic behavior of the elderly and the SG, who are middle-aged. Their use of the native variant of Al Silah was very low. It was $9.0 \%$ among males and $8.0 \%$ among females. The [g] variant is used in $81.0 \%$ of the total number of occurrences of the variable (Q) 
in the speech of young males. So, they have abandoned the $/ \mathrm{k} /$ in favor of the local variant which is the most salient feature denoting the social meaning of locality as it "symbolises Jordanian identity" (Al-Wer, 1991: 75). This is expected linguistic behavior as

"[o]ver the years, the comprehension between language and ethnic group or nation has changed. It was mainly due to political events" (Ashrapova et al., 2019: 45).

The linguistic form is not important in itself but rather as the symbolic role it has in the speech community (TSUI \& Tollefson, 2017). Thus, the use of the local variant became a way to associate oneself with the group and identify themselves as Jordanians since the problem of identity is connected with the identification process (Ashrapova \& Zamaletdino, 2018).

The elderly are preservers based on their age, and their communities put pressure on them to preserve their native dialect. The SG group preserves the dialect due to the factors related to the nature of their immigration and the environment where they settled. The young have not lived in their native village, nor do they live in a situation similar to that in which the middle-aged group experienced; that is, the SG primarily spent their lives in the same neighborhood. The younger generation left the Stair neighborhood and scattered to different places in the city. In dispersing, they did not remain a majority, which limited their influence socially, and this naturally led to their adoption of the linguistic behavior associated with the dominating group and the local majority. Thus, adopting the key feature of the local dialect, namely the $\mathrm{g} / \mathrm{variant}$ in young males and the urban glottal stop variant in young females, became a necessity. Each gender adopted the linguistic form reflective of its social nature. Young males adopted the local variant at a high rate $(81.0 \%)$; it is not unexpected that young Silawis should adopt the local variant as

"males appear to favor more localized variants, which carry some kind of identity-based social meaning in the local community" (Milroy \& Milroy, 1997: 55).

Milroy adds that

"[f]emales tend toward the careful end of the continuum and males toward the casual end. Similarly, it can be said that females favor prestige norms and males - vernacular norms" (Milroy, 1987: 55). 
Young females adopted the urban variant at a high rate $(90.0 \%)$ as it suits their nature to appear softer and more urbanized through the use of a variant associated with large urban centers in the Arab world such as Cairo, Jerusalem and Damascus (Ibrahim, 1986). Young Silawi females used the [?] variant in $90.0 \%$ of the total number of occurrences of the (Q) variable in their speech. SPSS analysis shows that gender has a very powerful significance in the use of the [?] variant among the young age group $(\mathrm{P}<.05$ while $\mathrm{P}<000$ for gender in the use of the [?] variant).

\section{Discussion}

The findings in the two study groups show that the linguistic behavior of the older generation was almost the same in that the elderly in both groups exhibited a very high percentage of preservation of the native variants. This is an expected linguistic behavior as this group is subject to strong social pressure to preserve their native dialects. Eckert also reports that

"community studies of variation frequently show that increasing age correlates with increasing conservatism in speech" (Eckert, 1997: 157).

The significant difference in the speech of the two groups is clearly seen in the speech of the middle-aged group. The native variant is used in $78.0 \%$ by elderly males and $67.0 \%$ by elderly females while the key feature of Tirawis was used in $10.0 \%$ by middle-aged Tirawi males and $6.0 \%$ by middle-aged Tirawi females. All of the political and social factors mentioned with regard to these two groups are important and jointly influenced this outcome. Tirawis found themselves alone without any kind of tethering to their origins in Jordan. Tirawis were identified as Palestinians while they were living in their native Palestine. They found themselves among a majority group and were the first Palestinians to immigrate to Jordan. There had no relatives in or any kind of official ties to the eastern banks of the Jordan River. They were also unable to return to their native country as it is occupied. Everyone in the village was forced to leave, so no relatives had remained there. Nor were connections maintained with other relatives in the native country 
who could help to preserve the native dialect and promote it through mutual visits.

Thus, Tirawis had no choice but to associate themselves with the majority group and integrate into it. In order to do so, they had to abandon any feature that would reveal their origin. In this case, the tongue is the most important feature to conceal. To integrate into the majority group, one must adopt the same dialect. Therefore, new generations of the Tirawis had no choice but to abandon their dialect, specifically the native key feature the /q/ variant as this variant in particular is not used at all in the Jordanian phonetic inventory. In addition to the factor of age, elder Tirawis had hoped to return to their native country. So, the preservation of their own dialect was possible and had motives. Beginning with the middle-aged group, newer generations began to abandon this hope, and, with it, they started abandoning an important link that associated them with their native land, i.e. the dialect. Realistically, they became involved within the country and they found themselves engaging in the different aspects of the Jordanian social and political life. Thus, all the factors that influence the abandonment of one's dialect became inevitable. Given this, it was not uncommon to find the dialect in the linguistic behavior of the young as in the case of the middle-aged group. The native variant was used in $6.0 \%$ in the total number of the occurrences of the $(\mathrm{Q})$ variable in the speech of young males, and $3.0 \%$ in the speech of young females.

The linguistic situation is different in the case of the Silawi group. Many factors that did not exist for Tirawis thus played a role in preserving the native dialect among Silawis. When Silawis first immigrated to Jordan in 1967 they found many of their relatives living in Jordan as the West Bank was part of Jordan at that time. Secondly, Silawis were able to live in Jordan or return to Al Silah. As a result, they maintained contact with the native dialect of Silawis. Thirdly, many of their relatives who stayed in Al Silah continued to visit them, and so exposure to their native dialect was still a contributing factor. Nevertheless, after the fak alairtibat, the similarities between the situation of the two groups increased, and as a result, the linguistic behavior of the younger generations became almost identical. In the Silawi group of the study, the young generations are at an age in which personal motivation is the greatest influential factor. A sense of belonging is very important in this regard. To be part of the local 
identity yet to use another dialect presents a great contradiction. Thus, adopting the local dialect became a necessity. So, it was not unexpected to find that the local [g] variant is used in $94.0 \%$ of the total number of occurrences of the variable $(\mathrm{Q})$ in the speech of young Tirawi males. It is the most salient feature carrying the social meaning of locality and "symbolises Jordanian identity" (Al-Wer, 1991: 75). Young Silawis behave almost similarly as young males used the native variant only in $9.0 \%$ and young females in $8.0 \%$ of the total number of occurrences of the $(\mathrm{Q})$ variable. Consequently, when the social and political context of both groups became almost similar, the linguistic behavior began to show a nearly identical pattern. So, the strong relation between social and political factors is crystalized in the case of these two groups.

\section{Conclusion}

The study compares two groups of Palestinians who immigrated to Jordan. In many respects, the groups are identical as they share the same native origins, culture, tradition, and history. The difference, however, lies in when they immigrated and in the political status of their Palestinian village at that time. This difference then manifested itself the linguistic behavior of both groups. The social and political situations of each group thus determined, to a great extent, the linguistic behavior they adopted. The linguistic behavior of the elderly remained almost unchanged. The social pressure they experienced to preserve their native dialects is the crucial factor that played a major role in its preservation. The linguistic behaviors of the two groups began to diverge when some political and social factors interfered in the life of these two groups. While the Silawis were treated as Jordanians because the Jordanian annexation of the West Bank formally occurred on 24 April 1950, Tirawis were treated as Palestinian refugees although they had also been granted Jordanian citizenship upon arrival. As a result, while Tiraiws lived in refugee camps, Silawis did not. Thus, Tirawis did not feel socially empowered as the Silawis did. This, we argue, was a major influential factor that enabled the first two generations of Silawis (the older and the middle-aged groups) to preserve their dialect. They considered themselves a Jordanian group with a dialect variety. The fact that Al Silah was part of the West Bank, which was, in turn, part 
of Jordan, strengthened this conviction and gave them a politically and socially legitimate status. This political situation remained as such until the disengagement decision between Jordan and the occupied West Bank in 1988. Then the political description of the two groups became the same, and afterwards, the linguistic behavior of the younger generations who were born after this political decision or were very young at the time consequently became nearly identical as the study shows. To conclude, the study shows a strong and inherent relation between the language used and the political status of the two immigrant groups studied. It demonstrates that any change in their political and social status triggered a change in the linguistic behavior.

\section{References}

Abdel-Jawad, H. (1981). Lexical and Phonological Variation in Spoken Arabic in Amman. [Unpublished doctoral dissertation]. University of Pennsylvania.

Al-Jehani, N. (1985). Sociostylistic stratification of Arabic in Makkah. [Unpublished doctoral dissertation]. University of Michigan.

Al Khatib, M. (1988). Sociolinguistic Change in an Expanding urban Context: a Case Study of Irbid city, Jordan. [Unpublished PhD thesis]. University of Durham.

Al-Wer, E. (1991). Phonological Variation in the Speech of Women from Three Urban Areas in Jordan. [Unpublished PhD Thesis]. University of Essex.

Al Zu'bi, A. (2001). Al Taghayyur al-taariikhi lil-'asswaat fi l-9arabiyya w-al-lughaat as-saamiyya (diraasa muqaaranah). [Unpublished $\mathrm{PhD}$ thesis]. The University of Jordan.

Amara, M., Spolsky, B., \& Tushyeh, H. (1999). Sociolinguictic of socio-political Patterns in Bethlehem: preliminary studies. Language and Society in the Middle East and North Africa, Studies in Variation and Identity, 1(1), 58-80.

Ashrapova, A., \& Zamaletdino, R. (2018). "Code-Switching and Linguistic Identity". Modern Journal of Language Teaching Methods, 8(11), 124-132.

Ashrapova, A, Litvinenko, E., \& Shakirova, D. (2019). Language Identity and its Context Policies. Articulos, Utopia Ypraxis Latinoamericana, 24(5), 44-50.

Bakir, M. (1986). Sex Differences in the Approximation to Standard Arabic: a case study. Anthropological Linguistics, 28, 3-9.

Bum, K, Kim, J, Chen, L.Y., \& Xu, L. (2019). Quality of Life of Elderly Chinese Immigrants: Focusing on Living Arrangements and Social Capital. Educational Gerontology, 45(6), 377-389. https://doi.org/10.1080/03601277.2019.1640973

Cho Kim, S. (2019). Post-War Immigration Experiences of Survivors of the Korean War. Journal of Aggression, Maltreatment \& Trauma, 28(8), 977-995. https://doi. org/10.1080/10926771.2017.1392388

Daher, J. (1998). Gender In linguistic Variation: The variable (Q) in Damascus Arabic. In E. Benmamoun, M. Eid \& N. Haeri (Eds.), Perspectives on Arabic linguistics (Vol. XI, pp. 183-205). Benjamins Publishing Company. https://doi.org/10.1075/ cilt.167.13dah 
Eckert, P. (1997). Age as a Sociolinguistic Variable. The Handbook of Sociolinguistics, 151-168. https://doi.org/10.1002/9781405166256.ch9

El Salman, M. (1991). Tirat Haifa between 1900-1948. Irbid: Qadisyyah Publisher.

El Salman, M. (2003). The Use of the /q/ Variant in the Arabic Dialect of Tirat Haifa. Anthropological Linguistics, 45(4), 413-426.

El Salman, M. (2006). Tragedy in Tirat Haifa. Irbid: Al Amal Press.

El Salman, M. (2021). "Variation in the Speech of Two Palestinian Immigrant Groups". Harvard Dataverse, V1. https://doi.org/10.7910/DVN/RFNGKB

Esposito, A., \& Baker-Ward, L. (2016). Immigration, Language Proficiency, and Autobiographical Memories: Lifespan Distribution and Second-language Access. Memory, 24(7), 949-960. https://doi.org/10.1080/09658211.2015.1061010

Ibrahim, M. (1986). Standard and Prestige Language: A Problem in Arabic sociolinguistics. Anthropological Linguistics, 28, 115-126.

Kanovsky, E. (1976). The Economy of Jordan. Tel Aviv: University Publishing Projects.

Low, E. (2008). Forgotten Conscripts: Prelude to Palestine's Struggle for Survival. Indiana: Trafford.

Milroy, J., \& Milroy, L. (1997). Varieties and Variation. In F. Coulmas (Ed.), The Handbook of Sociolinguistics (pp. 47-64). Blackwell.

Muelinen, G. (1908). Contributions to the Knowledge of Mt. Carmel. Separate printing from the Journal of the German Palestine Society, XXX(1907), 117207; XXXI(1908), 1-258. In El Salman, M. (Ed.), Graves, A. (Transl.).

Myers-Scotton, C.M. (1997). Code-switching. In F. Coulmas (Ed), The handbook of socio-linguistics (pp. 217-237). Cambridge: Blackwell Publishers. https://doi. org/10.1002/9781405166256.ch13

Myers-Scotton, C.M. (1995). Social Motivations for Code Switching: Evidence from Africa. Oxford: Clarendon Press.

Mazraani, N. (1997). Aspects of Language Variation in Arabic Political Speechmaking. London: TJ Press International.

Milroy, L. (1987). Language and Social Networks. Oxford: Blackwell.

Raymond, S. (2019). Journey into Europe: Islam, Immigration, and Identity. Journal of International \& Global Studies, 10(2), 142-146.

TSUI, A., \& Tollefson, J. (2017). Language Policy and the Construction of National Cultural Identity. Language Policy, Culture, and Identity in Asian Contexts (pp. 1-22). Routledge. https://doi.org/10.4324/9781315092034-1

Wachter, G., \& Fleischmann, F. (2018). Settlement Intentions and Immigrant Integration: The Case of Recently Arrived EU-Immigrants in the Netherlands. International Migration, 56(4), 154-171. https://doi.org/10.1111/imig.12434

Walters, K. (1991). Women, men, and linguistic variation in the Arab world. In B. Comrie \& M. Eid (Eds.), Perspectives on Arabic linguistics (Vol. 3, pp. 197229). Amsterdam: John Benjamins Publishing Company.

\section{АНОТАЦІЯ}

Мета. Це соціолінгвістичне дослідження спрямоване на те, щоб уважно вивчити відмінності і подібності в мовній поведінці двох палестинських груп $і$ проаналізувати їх в світлі соціальних і політичних факторів. 
Mетоди. У дослідженні використовується лабовіанськая парадигма, а для збору даних використовуються методи особистого спілкування.

Результати. Перша група іммігрувала до Йорданії з Палестини в результаті вигнання зі своїх будинків у 1948 році. Вони приїхали шукати притулку в Йорданії, і, оскільки вони прибули з Палестини, з ними поводилися як з такими. Коли майже два десятиліття по тому почалася арабо-ізраїльська війна, нова хвиля палестинців мігрувала до Йорданії в 1967 році. Однак у той час їх палестинське село політично належало Йорданії, тому що Йорданія анексувала Західний берег у 1950 році. Таким чином, політичний статус обох груп палестинців на початку їх виходу зіграв важливу роль у подальшому розвитку їхньої мовної поведінки в Йорданії. Це вплинуло на варіації в їхній мові. До перших прибулих людей ставилися як до палестинських біженців, що зводило їх до мінімуму з сочіальної точки зору. Таким чином, дослідження показує, що представники середнього і молодого покоління цієї етнічної групи відмовилися від діалекту, а 98.0\% з них використовували місцевий варіант. До осіб другої групи мігрантів ставилися як до громадян Йорданії, оскільки вони просто мігрували з однієї частини країни, а саме із Західного берега, в іншу іï частину, а саме на Східний берег (Йорданія). Дослідження виявило сильну кореляцію між особистістю людини і політичним статусом, наданим країною. Хоча члени обох груп є палестинцями, дослідження показує, що всі люди вели себе лінгвістично по-різному залежно від того, як вони сприймалися соціально $і$ політично в Йорданії.

Висновки. Палестинці емігрували двома великими хвилями зі своєї батьківщини до Йорданії у результаті війни. Перша відбулась у 1948 році, а друга - в 1967 році. Дослідження показує, що мовна поведінка обох груп відрізняється. Сочіальні та політичні ситуації, в яких опинилася кожна група, значною мірою визначили лінгвістичну поведінку, яку вони прийняли.

Ключові слова: мовна поведінка, варіант, мовне співтовариство, ідентичність.

\section{Ель Салман Махмуд. Вариация речи двух палестинских иммигрантских групп}

\section{АННОТАЦИЯ}

Цель. Это социолингвистическое исследование направлено на то, чтобы внимательно изучить различия и сходства в языковом поведении двух палестинских групп и проанализировать их в свете социальных и политических факторов.

Методы. В исследовании используется лабовианская парадигма, а для сбора данных используются методы личного общения.

Результаты. Первая группа иммигрировала в Иорданию из Палестины в результате изгнания из своих домов в 1948 году. Они приехали искать убежища в Иордании, и, поскольку они прибыли из Палестины, с ними обращались как с таковыми. Когда почти два десятилетия спустя началась арабо-израильская война, новая волна палестинцев мигрировала в Иорданию в 1967 году. Однако 
в то время их палестинская деревня политически принадлежала Иордании, потому что Иордания аннексировала Западный берег в 1950 году. Таким образом, политический статус обеих групп палестинцев в начале их исхода сыграл важную роль в последующем развитии их языкового поведения в Иордании. Это повлияло на вариации в их речи. К первым прибывшим людям относились как к палестинским беженцам, что сводило их к минимуму с социальной точки зрения. Таким образом, исследование показывает, что представители среднего и молодого поколения этой этнической группы отказались от диалекта, а 98.0\% из них приняли местный вариант. $K$ лицам второй группы мигрантов относились как к гражданам Иордании, поскольку они просто мигрировали из одной части страны, а именно с Западного берега, в другую ее часть, а именно на Восточный берег (Иордания). Исследование обнаружило сильную корреляцию между личностью человека и политическим статусом, предоставленным страной. Хотя члены обеих групп являются палестинцами, исследование показывает, что все люди вели себя лингвистически по-разному, в зависимости от того, как они воспринимались социально и политически в Иордании.

Заключение. Палестинцы эмигрировали двумя большими волнами со своей родины в Иорданию в результате войны. Первая произошла в 1948 году, а вторая - в 1967 году. Исследование показывает, что языковое поведение обеих групп различается. Социальные и политические ситуации, в которых оказалась каждая группа, в значительной степени определили лингвистическое поведение, которое они приняли.

Ключевые слова: языковое поведение, вариант, речевое сообщество, идентичность. 